Sacred Marriages 



\title{
Sacred Marriages
}

\section{The Divine-Human Sexual Metaphor from} Sumer to Early Christianity

\author{
Edited by \\ MartTi Nissinen and Risto Uro
}

Winona Lake, Indiana

EISENBRAUNS

2008 
(C) Copyright 2008 by Eisenbrauns.

All rights reserved.

Printed in the United States of America.

www.eisenbrauns.com

\section{Library of Congress Cataloging-in-Publication Data}

Sacred marriages : the divine-human sexual metaphor from Sumer to early Christianity / edited by Martti Nissinen and Risto Uro.

p. $\mathrm{cm}$.

Includes bibliographical references and indexes.

ISBN-13: 978-1-57506-118-4 (hardback : alk. paper)

1. Marriage-Religious aspects. 2. Spirituality. I. Nissinen, Martti.

II. Uro, Risto.

BL462.S33 2008

$204^{\prime} .41-\mathrm{dc} 22$

The paper used in this publication meets the minimum requirements of the American National Standard for Information Sciences-Permanence of Paper for Printed Library Materials, ANSI Z39.48-1984. @ ${ }^{\mathrm{TM}}$ 